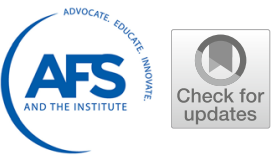

\title{
THE ROLE OF PRIMARY AUSTENITE MORPHOLOGY IN HYPOEUTECTIC COMPACTED GRAPHITE IRON ALLOYS
}

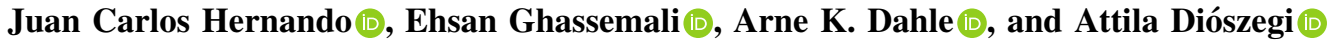 \\ Department of Materials and Manufacturing, School of Engineering, Jönköping University, 55111 Jönköping, Sweden \\ Jessica Elfsberg \\ Scania CV AB, 15187 Södertälje, Sweden
}

Copyright $(\subset) 2020$ The Author(s)

https://doi.org/10.1007/s40962-020-00410-9

\begin{abstract}
This work investigates the role of primary austenite morphology on the eutectic and eutectoid microstructures and the ultimate tensile strength (UTS) in a hypoeutectic compacted graphite iron (CGI) alloy. The morphology of primary austenite is modified by isothermal coarsening experiments in which holding times up to $60 \mathrm{~min}$ are applied to the solid-liquid region after coherency. The cooling conditions for the subsequent eutectic and eutectoid reactions are similar. Miniaturized tensile tests are

eutectoid microstructures are not significantly affected by the morphology of primary austenite, thus indicating that the morphology of the interdendritic regions does not control the nucleation frequency and growth of eutectic cells or graphite. UTS decreases linearly with the increasing coarseness of primary austenite for similar eutectic and eutectoid microstructures, demonstrating the strong influence of primary austenite morphology on the UTS in hypoeutectic CGI alloys.
\end{abstract} performed to evaluate the UTS. The morphological characteristics related to the surface area of primary austenite, the modulus of primary austenite, $M_{\gamma}$, and the hydraulic diameter of the interdendritic region, $D_{\mathrm{ID}}^{\mathrm{Hyd}}$, increase with the cube root of coarsening time. The eutectic and
Keywords: cast iron, compacted graphite iron, CGI, solidification, dendrites, primary austenite, UTS

\section{Introduction}

Global environmental targets demand improved performance and fuel economy. Urged by these goals, automotive manufacturers strive to design improved fuel-efficient engines, which entail higher peak pressures during operation and thus subject the material to higher thermal and mechanical loads. In this context, the exceptional balance between thermal and mechanical properties achieved with compacted graphite cast iron (CGI) alloys ${ }^{1}$ makes them a preferred material for structural elements in heavy-duty engines, such as cylinder heads or cylinder blocks. The further development of the material application is challenged by the limited availability of accurate

This paper is an invited submission to IJMC selected from presentations at the 2nd Carl Loper 2019 Cast Iron Symposium held September 30 to October 1, 2019, in Bilbao, Spain. microstructure-property relations available in the literature $^{2,3}$ and our ability to avoid the possible appearance of defects during solidification. Thus, a better understanding and prediction of the microstructure formation during solidification is essential to optimize the use and production of CGI.

In hypoeutectic cast iron alloys, primary austenite forms dendritic microstructures, which coarsen during solidification. ${ }^{4}$ During coarsening, the solid-liquid region formed by the dendrites and the surrounding liquid reduces its total interfacial area. ${ }^{5}$ This increases the length scale of the dendrites, ${ }^{6}$ promoting significant morphological changes in the primary austenite crystals. ${ }^{7}$ Large dendrite arms thicken following an Ostwald ripening process ${ }^{8}$ in which their length scale, e.g., the secondary dendrite arm spacing (SDAS), is proportional to the cube root of total solidification time, $t^{1 / 3} \cdot{ }^{4}$ Further coarsening leads to a globular 
appearance of the microstructure ${ }^{7}$ as a result of dendrite fragmentation ${ }^{9}$ and coalescence of crystals, ${ }^{10}$ challenging an accurate measurement of the SDAS. To describe the morphology of heavily coarsened microstructures, shapeindependent morphological parameters, such as the interfacial area, have been proposed. ${ }^{8}$ Recent work has shown that these parameters follow the same relation to $t^{1 / 3}$ for the three main cast iron alloys, i.e., lamellar (LGI), compacted (CGI), and spheroidal graphite iron (SGI). ${ }^{11}$ After dendrite coherency, free growth stops, coarsening becomes the dominant growth mechanism, and the feeding changes from mass to interdendritic. ${ }^{12}$ At this point, the morphology of primary dendrites will determine the morphology of the interdendritic regions where the eutectic reaction will occur. $^{13}$

During the eutectic reaction in CGI, compacted graphite and eutectic austenite grow cooperatively until the end of solidification, ${ }^{14,15}$ forming three-dimensional eutectic cells in the interdendritic regions. ${ }^{16}$ Graphite nucleates on preexisting inclusions in the liquid, ${ }^{17}$ and its growth is controlled by the segregation of some trace elements. ${ }^{18}$ In particular, the presence of $\mathrm{O}$ and $\mathrm{S}$ is detrimental to the formation of CGI, and their impact on the nodularity of the alloy is critical. ${ }^{19} \mathrm{~A}$ nodularization treatment is performed to reduce the level of $\mathrm{O}$ and $\mathrm{S} . \mathrm{Mg}$ is the most common element for this purpose. This treatment is challenging, as the production of compacted graphite only occurs within a very narrow window of $\mathrm{Mg}$ contents. ${ }^{20,21}$ Outside this window, lower values of $\mathrm{Mg}$ promote LGI, while higher values result in nodularities over $20 \%$, not accepted in CGI production, due to an excessive presence of graphite spheroids. ${ }^{22}$ A further complication appears as $\mathrm{Mg}$ fades with time, thus needing strict control during processing. ${ }^{19,23-25}$

In solid state, during the eutectoid reaction, austenite transforms into pearlite, ferrite, or a mixture of these phases. ${ }^{26}$ The chemical composition and cooling conditions control the fraction of these phases. However, the formation of ferrite in CGI is promoted by the morphology of compacted graphite. ${ }^{1}$

Models relating microstructure and mechanical properties in CGI are scarce in the literature. However, several relations have been proposed for the ultimate tensile strength (UTS) in LGI, which shares a similar fracture mode with CGI. Most of them use the shape and distribution of graphite as modeling parameters. Applying the Griffith fracture model for brittle materials, ${ }^{27}$ the maximum length of graphite is used to determine the UTS. ${ }^{28,29}$ The influence of eutectic cell size is not clear, as literature shows contradictory results. Several studies report that UTS decreases with the size of eutectic cells $\mathrm{s}^{30,31}$, while the opposite effect has also been reported, indicating the lowest UTS for the smallest eutectic cell size. ${ }^{13}$ Furthermore, the size of eutectic cells in LGI was correlated to the SDAS of the primary austenite, ${ }^{32}$ suggesting a connection between the morphologies of primary and eutectic microstructures. Besides, the effect of the eutectoid microstructure was incorporated into the model by including the pearlite lamellar spacing (PLS) using a Hall-Petch type equation. ${ }^{33}$

In recent studies, the UTS of pearlitic LGI was correlated with the morphology of primary austenite in hypoeutectic alloys. ${ }^{34}$ The UTS decreased for coarsened dendritic microstructures, showing a linear relation to the morphology of the interdendritic regions regardless of the maximum graphite length and the size and distribution of the eutectic cells. The interdendritic region, which represents the volume between dendrites where eutectic cells grow, substitutes the graphite length in the traditional Griffith equation for the prediction of the UTS in LGI. However, the study was performed with experimental conditions yielding simultaneous variations in primary, eutectic, and eutectoid microstructures. ${ }^{34}$

This work aims to increase the understanding of the correlation between microstructure and the mechanical properties in hypoeutectic CGI alloys. The main objective is to study the role of primary austenite morphology on the eutectic and eutectoid microstructures, and on the UTS of hypoeutectic CGI alloys at room temperature. To that purpose, the morphology of primary austenite is modified by isothermal coarsening, leaving the cooling conditions during the subsequent eutectic and eutectoid reactions unaffected. Miniaturized tensile tests (MTT) are performed to evaluate the influence of primary austenite morphology on UTS.

\section{Experimental}

\section{Experimental Alloy}

The experimental alloy used in this work was a hypoeutectic $\mathrm{Fe}-\mathrm{C}-\mathrm{Si}$ alloy treated with $\mathrm{Mg}$ to solidify as SGI. $\mathrm{Mn}, \mathrm{Cu}$, and $\mathrm{Sn}$ were added to promote pearlite during the eutectoid transformation. ${ }^{35}$ The chemical composition of the alloy was determined by optical emission spectrometry $(\mathrm{OES})^{36}$ on graphite-free white chilled coins produced immediately before the pouring. A composition of $3.4 \% \mathrm{C}$, $2.5 \% \mathrm{Si}, 0.03 \% \mathrm{P}, 0.01 \% \mathrm{~S}, 0.063 \% \mathrm{Mg}, 0.7 \% \mathrm{Mn}, 0.1 \% \mathrm{Sn}$, $0.9 \% \mathrm{Cu}(\mathrm{wt} \%)$ was determined. The alloy was cast into sand molds in the shape of rods of $50 \mathrm{~mm}$ diameter and $300 \mathrm{~mm}$ height that were subsequently machined to a weight of $400 \pm 0.5 \mathrm{~g}$, yielding a diameter of $38 \mathrm{~mm}$ and a height of $42 \mathrm{~mm}$.

\section{Solidification Experiments}

Solidification experiments were conducted inside an electrical resistance furnace to modify the chemical composition to produce CGI and to study the thermal coherency of 
the experimental alloy. The rods were re-melted and held at $1450{ }^{\circ} \mathrm{C}$ inside a 40 -mm-diameter alumina crucible under Ar atmosphere. The holding time at $1450{ }^{\circ} \mathrm{C}$ was adjusted during the experiment to reach a composition corresponding to CGI by lowering the residual $\mathrm{Mg}$ in the alloy. ${ }^{37}$ Based on previous research and preliminary experiments, the holding time at $1450{ }^{\circ} \mathrm{C}$ to produce a CGI with a nodularity lower than $5 \%$ from the experimental SGI material used in this work was set to $80 \mathrm{~min}^{37}$

After the holding time at $1450{ }^{\circ} \mathrm{C}$, the samples were cooled inside the furnace, and thermal analysis was conducted during solidification. Thermal coherency was determined to be at $1167^{\circ} \mathrm{C}$, indicating the moment when a coherent dendritic microstructure has been formed. ${ }^{12}$

\section{Isothermal Coarsening Experiments}

The cooling curves from the solidification experiments were used to design an isothermal treatment to coarsen the primary austenite after thermal coherency. The experimental procedure during the isothermal coarsening experiments is as follows. The rods were re-melted using the same conditions used in the solidification experiments, i.e., melted and held at $1450{ }^{\circ} \mathrm{C}$ for $80 \mathrm{~min}$. Then, the samples were cooled inside the furnace to $1163{ }^{\circ} \mathrm{C}$, above the eutectic temperature for this alloy to avoid the interaction between the coarsening of primary austenite and the nucleation and growth of the eutectic microstructure. Next, the samples were held isothermally for different times $(0$, 10 , 30, and $60 \mathrm{~min}$ ) to promote the coarsening of the dendrites. During isothermal coarsening, the solid fraction should remain constant, as the solidification is halted. The primary austenite microstructure is then coarsened with no influence of the eutectic microstructure as shown in previous work using interrupted solidification experiments. ${ }^{38}$ After the coarsening time, the samples were cooled to room temperature inside the furnace, providing similar cooling conditions for the eutectic solidification and eutectoid transformation. Further details on the experimental methodology can be found elsewhere. ${ }^{11,39}$

\section{Miniaturized Tensile Tests}

From the samples from the isothermal coarsening experiments, miniaturized tensile bars of $40 \mathrm{~mm}$ length were machined and polished. The tensile bars were extracted at a half-radius distance from the center of the cylinder. Dimensions of the tensile bars are shown in Figure 1. The thickness of the bars is $1.8 \pm 0.2 \mathrm{~mm}$ in order to contain several CGI eutectic cells. Miniaturized tensile tests (MTT) were performed at room temperature in a loading stage (produced by Kamath \& Weiss) with a crosshead displacement rate of $10 \mu \mathrm{m} / \mathrm{s}$. Four bars were tested for each condition. After the MMT, the samples were etched in a

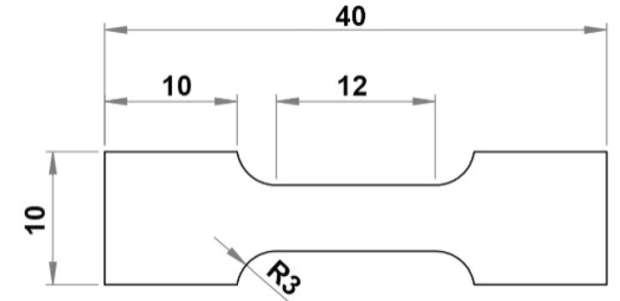

Figure 1. Dimensions of the tensile bars for the miniaturized tensile tests (MTT).

picric-based solution to reveal the microstructure and observe the austenite dendrites. ${ }^{40}$

\section{Microstructural Characterization}

The microstructural characterization was performed by optical and scanning electron microscopy (SEM). The micrographs of the etched samples were transformed into binary images. For each coarsening time, four random areas belonging to different regions of two different samples were analyzed, covering a total area of about $80 \mathrm{~mm}^{2}$. Two separate binary images were prepared from each area of analysis, as shown in Figure 2. One image was prepared for the primary austenite microstructure and one for the eutectic microstructure, enabling the measurement of different morphological characteristics using Olympus Stream Motion Desktop 1.9.1 software.

The secondary dendrite arm spacing (SDAS), commonly used in the literature to characterize coarsening of dendritic microstructures, ${ }^{41}$ was measured locally on dendritic microstructures including at least three secondary dendrite arms parallel to the primary arm. The area fraction $\left(f_{\gamma}\right)$, perimeter $\left(P_{\gamma}\right)$, and area $\left(A_{\gamma}\right)$ of primary austenite were measured on the same binary images. Morphological parameters were calculated from these measurements to perform a two-dimensional quantitative analysis of the morphological evolution of primary austenite during coarsening in CGI.

The modulus of primary austenite, $M_{\gamma}(\mu \mathrm{m})$, is defined as the ratio between the volume of primary austenite, $V_{\gamma}$ and surface area, $S_{\gamma}$. Stereological relations were applied ${ }^{42,43}$ to calculate this characteristic from a $2 \mathrm{D}$ investigation. Following those, $V_{\gamma}$ was approximated by $V_{\gamma} \approx A_{\gamma}$ and $S_{\gamma}$ by $S_{\gamma} \approx 4 / \pi P_{\gamma}$. Thus, $M_{\gamma} \quad(\mu \mathrm{m})$ was calculated as $M_{\gamma} \approx \pi / 4\left(A_{\gamma} / P_{\gamma}\right)$. In the same way, the hydraulic diameter of the interdendritic region, $D_{\mathrm{ID}}^{\mathrm{Hyd}}(\mu \mathrm{m})$, is defined as the ratio between the volume of the interdendritic region, $V_{\mathrm{ID}}$, and the surface area, $S_{\mathrm{ID}} . D_{\mathrm{ID}}^{\mathrm{Hyd}}$ is determined considering that the primary austenite and the interdendritic region share a common interfacial boundary, thus $S_{\text {ID }} \approx S_{\gamma}$. Applying the same stereological principles and the relationship between the area of primary austenite $\left(A_{\gamma}\right)$ and the total area of the micrograph $\left(A_{\mathrm{T}}\right)$, which defines the 


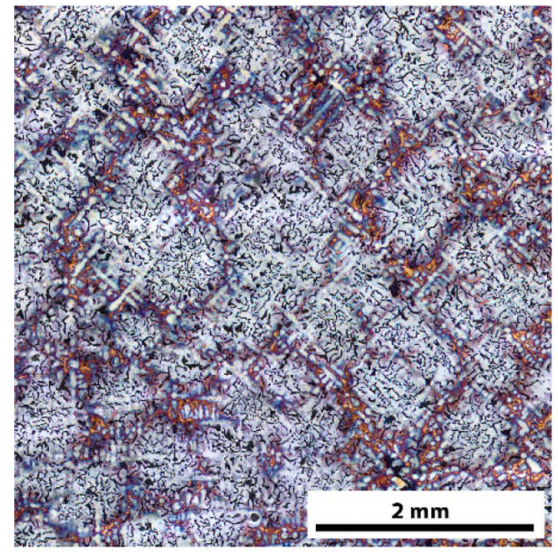

(a)

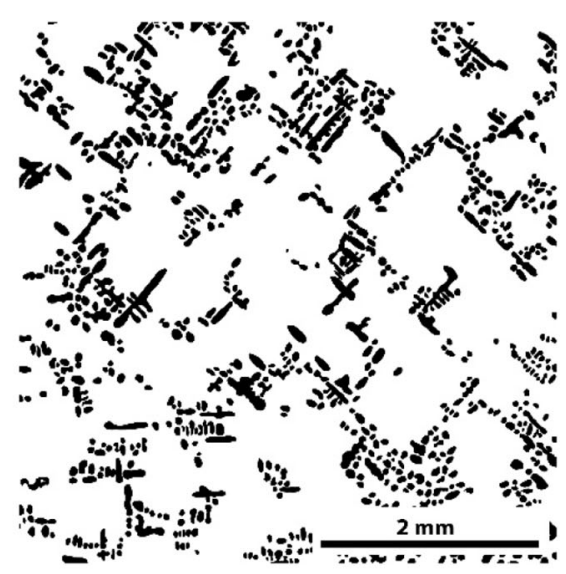

(b)

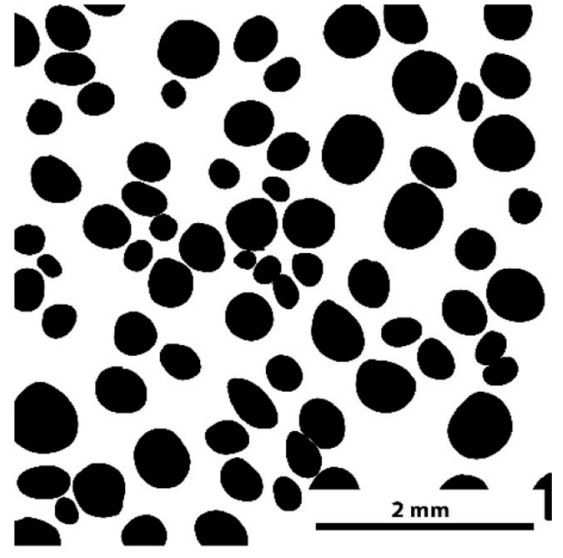

(c)

Figure 2. (a) Micrograph of an etched sample after 0 min of isothermal coarsening and the binary images of the same micrograph for (b) microstructural characterization of primary austenite, and (c) characterization of the eutectic microstructure.

area of the interdendritic region $\left(A_{\mathrm{ID}}\right)$ as $A_{\mathrm{ID}} \approx A_{\mathrm{T}}-A_{\gamma}$. Thus, the hydraulic diameter of the interdendritic region, $D_{\mathrm{ID}}^{\mathrm{Hyd}}, \quad$ is calculated as $D_{\mathrm{ID}}^{\mathrm{Hyd}} \approx \pi / 4\left(A_{\mathrm{ID}} / P_{\mathrm{ID}}\right) \approx$ $\pi / 4\left(\left(A_{\mathrm{T}}-A_{\gamma}\right) / P_{\gamma}\right)$. Additionally, the shortest distance between the center of gravity of a primary austenite crystal and its surrounding crystals, $D_{\gamma}^{\mathrm{NN}}(\mu \mathrm{m})$, was measured for all austenite crystals in the micrograph.

The eutectic microstructure was characterized by the area fraction $\left(f_{\mathrm{EC}}\right)$, number $\left(\mathrm{EC} / \mathrm{mm}^{2}\right)$, size $\left(\right.$ Diam $\left._{\mathrm{EC}}\right)$, and shortest distance $\left(D_{\mathrm{EC}}^{\mathrm{NN}}\right)$ between eutectic cells in the binary images. Furthermore, before the MTT, the nodularity, area fraction, graphite particle type, and the maximum length of graphite were calculated following ISO 16112:2006(E) ${ }^{44}$ on multiple regions of the sample covering a total area of about $24 \mathrm{~mm}^{2}$. The maximum length of graphite was calculated considering only the largest $1 \%$ of the graphite particles.

The pearlite lamellar spacing (PLS) was determined on SEM images, Figure 3. The SEM was operated at a constant magnification and an acceleration voltage of $15 \mathrm{kV}$. Ten images were taken for each sample, and the PLS was determined in the regions with the most refined pearlite containing at least 10 pearlite lamellae.

\section{Results and Discussion}

\section{Morphological Characteristics of Primary Austenite During Coarsening}

The microstructures resulting from the isothermal holding and the subsequent cooling to room temperature are shown in Figure 4. The micrographs show the morphological changes that occurred in the dendritic microstructure as a function of the coarsening time. The microstructure after

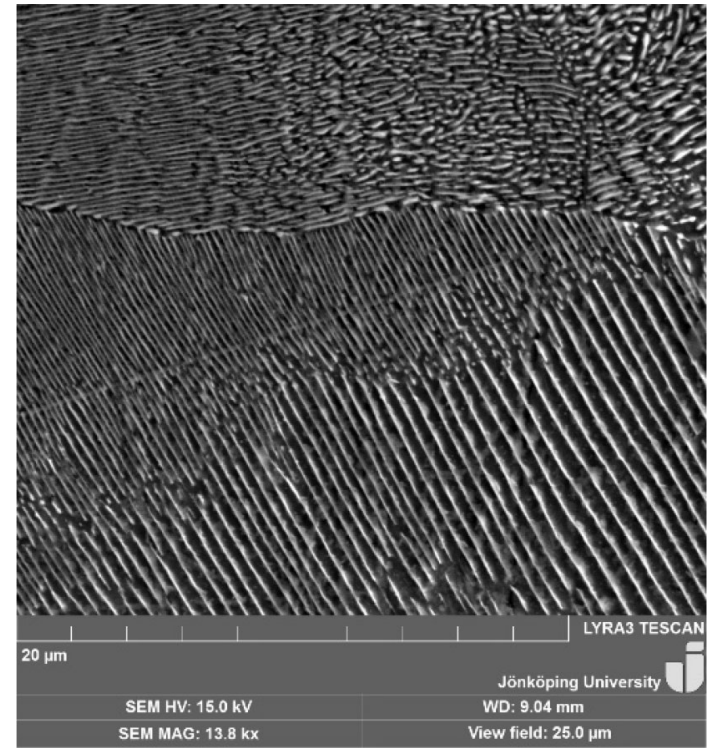

Figure 3. SEM image of a pearlitic region in the sample after 0 min of isothermal coarsening.

0 min of isothermal coarsening, Figure 4a, shows a dendritic network where highly branched and interconnected dendrites have impinged on each other and secondary dendrite arms are visible. As the isothermal holding time increases, for 10 and $30 \mathrm{~min}$, Figure $4 \mathrm{~b}$ and c, the effect of coarsening is more significant. The surface area of the dendrites is reduced, increasing the length scale, and an overall more globular microstructure is observed. This suggests that dendrite fragmentation occurs simultaneously with Ostwald ripening as a result of coarsening. In the regions where the secondary arms are visible, they appear thicker. After $60 \mathrm{~min}$ of isothermal holding, the microstructure shows more coarsened, almost globular, primary austenite crystals, Figure 4d. A regular arrangement of crystals is observed, suggesting the former dendritic microstructure, but, likely, these crystals are no 


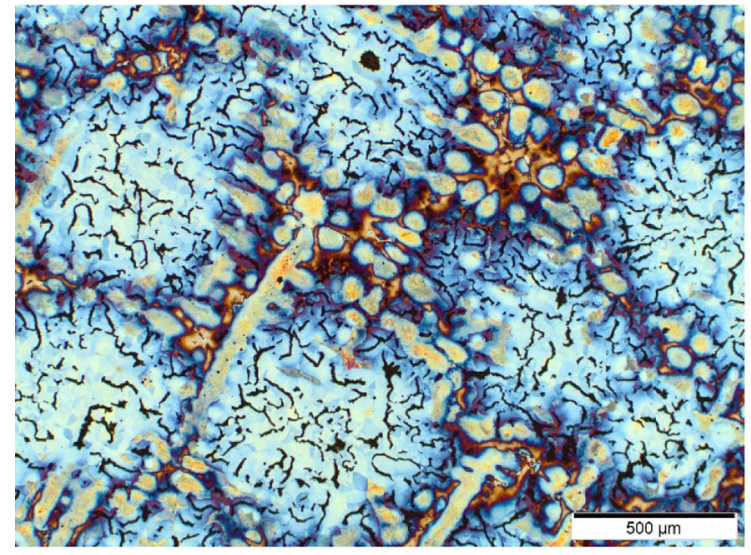

(a)

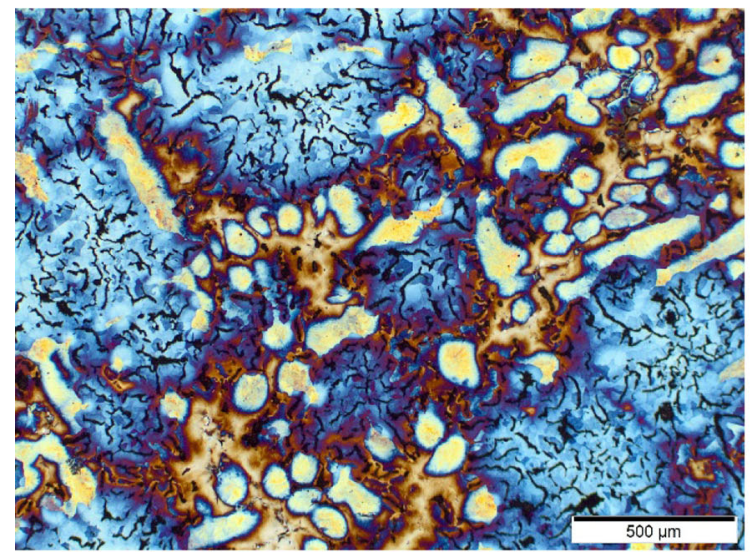

(c)

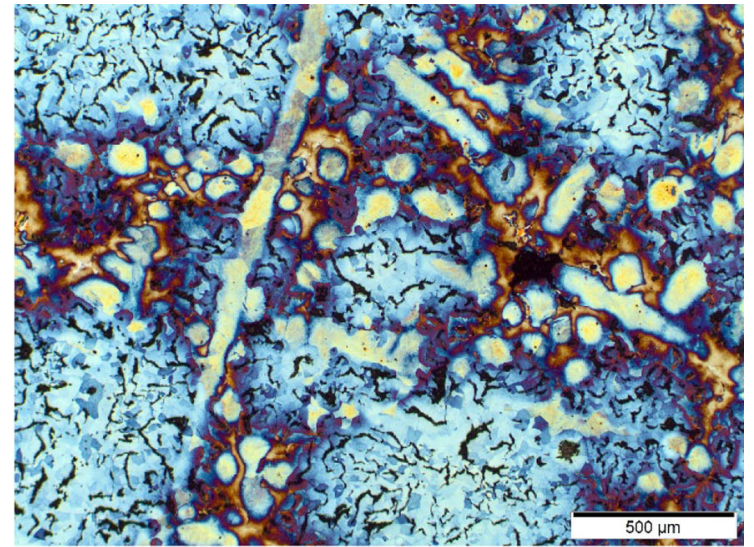

(b)

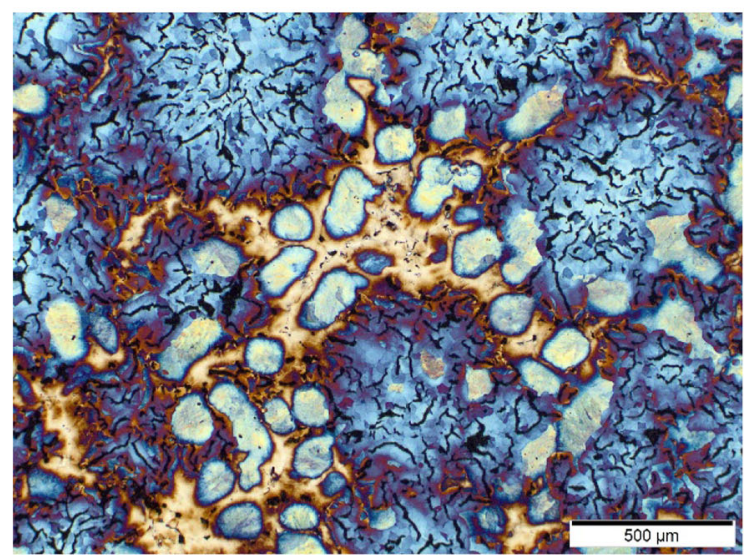

(d)

Figure 4. Micrographs of etched samples after (a) 0 , (b) 10, (c) 30, and (d) 60 min of isothermal coarsening.

Table 1. Microstructural Characteristics of Primary Austenite as a Function of Coarsening Time

\begin{tabular}{|c|c|c|c|c|c|}
\hline Coarsening time $(\mathrm{min})$ & $f_{\gamma}^{*}$ & $\operatorname{SDAS}(\mu \mathrm{m})$ & $M_{\gamma}(\mu \mathrm{m})$ & $D_{\mathrm{ID}}^{\mathrm{Hyd}}(\mu \mathrm{m})$ & $D_{\gamma}^{\mathrm{NN}}(\mu \mathrm{m})$ \\
\hline 0 & $0.35 \pm 0.05$ & $65 \pm 14$ & $16 \pm 1$ & $27 \pm 3$ & $95 \pm 6$ \\
\hline 10 & $0.36 \pm 0.02$ & $102 \pm 28$ & $20 \pm 1$ & $35 \pm 3$ & $127 \pm 6$ \\
\hline 30 & $0.34 \pm 0.01$ & $136 \pm 23$ & $21 \pm 1$ & $41 \pm 2$ & $142 \pm 9$ \\
\hline 60 & $0.37 \pm 0.03$ & $212 \pm 53$ & $27 \pm 1$ & $47 \pm 5$ & $183 \pm 5$ \\
\hline
\end{tabular}

The error shows the standard deviation

longer interconnected in three dimensions due to dendrite fragmentation. There are fewer crystals/globules than in previous micrographs, and indications of coalescence of austenite crystals can be observed.

The quantitative analysis of the morphological characteristics of primary austenite is based on the parameters described in the experimental section, $M_{\gamma}, D_{\gamma}, D_{\mathrm{ID}}^{\text {hyd }}$, and SDAS and shown in Table 1. The normalized fraction of austenite, $f_{\gamma}^{*}$, was determined from the measured fraction of austenite, $f_{\gamma}$, assuming a uniform distribution of primary austenite in the microstructure, even in regions covered by eutectic cells.
SDAS shows a linear relation with the cube root of coarsening time, $t^{1 / 3}$, up to $30 \mathrm{~min}$, as shown in Figure 5. This is in good agreement with the literature. ${ }^{4,41}$ However, after 60 min of coarsening, SDAS deviates from the previous samples and shows a significant scatter. This could be because SDAS was measured on a random 2-D section of the 3-D microstructure and detached arms may have moved in the liquid at this stage of coarsening. The modulus of primary austenite, $M_{\gamma}$, increases slightly with coarsening time as it represents the reduction in surface area to volume of primary austenite occurring during coarsening. In Figure 5, $M_{\gamma}$ is shown as a function of the cube root of coarsening time, $t^{1 / 3}$. We find a linear 


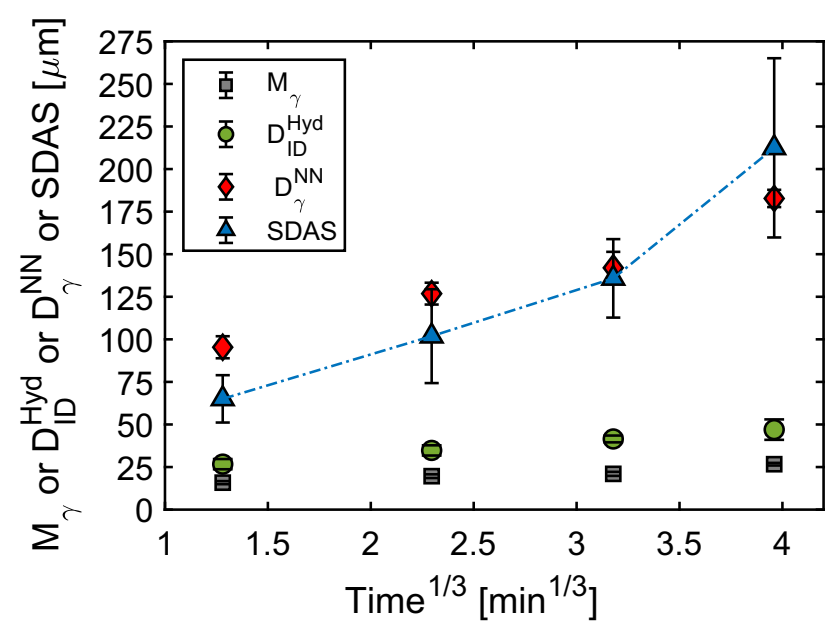

Figure 5. Microstructural characteristics of primary austenite as a function of coarsening time. The error bars show the standard deviation.

relationship for all the samples in this study. These results agree with results from quenching experiments in CGI reported previously ${ }^{38}$ and recent literature studying the evolution of interfacial area in dendritic microstructures of different alloys ${ }^{10,45}$ reporting a relation to $t^{1 / 3}$ for long coarsening times. Micrographs in Figure 4 also suggest a spatial redistribution of primary austenite crystals during coarsening, which is shown by the distance between primary austenite crystals, $D_{\gamma}^{\mathrm{NN}}$, increasing linearly with the cube root of coarsening time, $t^{1 / 3}$, as shown in Figure 5. Additionally, the changes in morphology and distribution of the dendritic microstructure necessarily change the morphology of the interdendritic region. The hydraulic diameter of the interdendritic region, $D_{\mathrm{ID}}^{\mathrm{Hyd}}$, calculated in a similar way to $M_{\gamma}$, shows the reduction in surface area and spatial redistribution of primary austenite during coarsening. $D_{\mathrm{ID}}^{\text {Hyd }}$ increases with coarsening time, Table 1 , as the surface area of the interdendritic region is reduced during coarsening. $D_{\mathrm{ID}}^{\mathrm{Hyd}}$ also follows a linear relationship with the cube root of coarsening time, $t^{1 / 3}$, as shown in Figure 5.

\section{Characteristics of Eutectic and Eutectoid Microstructures After Coarsening of Primary Austenite}

Micrographs in Figure 4 show eutectic cells comprised of compacted graphite particles and eutectic austenite in CGI for all the samples studied after different coarsening times. The morphology of primary austenite determines the interdendritic region where the eutectic microstructure will grow. This suggests a possible interrelation between both microstructures.

As shown in the previous section, the interdendritic region follows a linear relation with the cube root of coarsening time, $t^{1 / 3}$. However, the analysis of the nodularity, fraction, and maximum length of graphite shows that these
Table 2. Graphite Particle Characteristic as a Function of Coarsening Time

\begin{tabular}{llrl}
\hline $\begin{array}{l}\text { Coarsening time } \\
(\mathrm{min})\end{array}$ & $\begin{array}{l}\text { Nodularity ISO } \\
(\%)\end{array}$ & \multicolumn{1}{l}{$\begin{array}{l}\text { Fraction } \\
(\%)\end{array}$} & $L_{\mathrm{Gr}}^{\mathrm{Max}}(\mu \mathrm{m})$ \\
\hline 0 & $2.6 \pm 1.1$ & $9.9 \pm 0.7$ & $222 \pm 30$ \\
10 & $1.9 \pm 0.9$ & $10.5 \pm 0.9$ & $246 \pm 52$ \\
30 & $2.6 \pm 1.4$ & $9.9 \pm 1.0$ & $223 \pm 32$ \\
60 & $2.9 \pm 1.1$ & $10.6 \pm 1.1$ & $247 \pm 46$ \\
\hline
\end{tabular}

The error shows the standard deviation

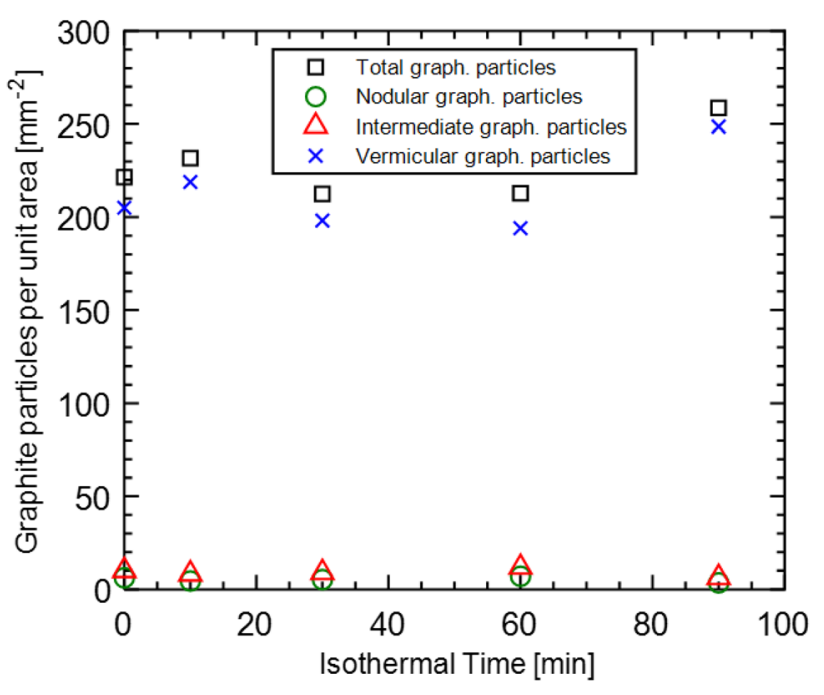

Figure 6. Distribution of graphite particle types as a function of coarsening time.

parameters corresponding to graphite do not follow the same trend and do not change considerably with coarsening time, Table 2. Furthermore, the distribution of graphite particles, based on the roundness shape factor (nodular, vermicular, and intermediate), is analyzed as a function of coarsening time. As shown in Figure 6, the total number of graphite particles and the number of vermicular graphite particles are similar for the different coarsening times. These results show that the growth of graphite in CGI is not significantly influenced by the morphology of primary austenite.

Eutectic cells in Figure 4 appear quite spherical, and it is difficult to distinguish any significant effect of the coarsening time on their morphology and number. Table 3 shows that the fraction $\left(f_{\mathrm{EC}}\right)$, number $\left(\mathrm{EC} / \mathrm{mm}^{2}\right)$, size $\left(\right.$ Diam $\left._{\mathrm{EC}}\right)$, and spatial distribution $\left(D_{\mathrm{EC}}^{\mathrm{NN}}\right)$ of eutectic cells are not significantly affected by coarsening time. As the number of eutectic cells is similar to the number of nucleation events occurring during the eutectic reaction, these results show that the morphology of primary austenite does not significantly influence the eutectic nucleation frequency in CGI. Thus, the surface area of 
Table 3. Microstructural Characteristics of Eutectic Cells as a Function of Coarsening Time

\begin{tabular}{lllll}
\hline $\begin{array}{l}\text { Coarsening } \\
\text { time }(\min )\end{array}$ & $f_{\mathrm{EC}}$ & $\mathrm{EC} / \mathrm{mm}^{2}$ & $\begin{array}{l}\mathrm{Diam}_{\mathrm{EC}} \\
(\mu \mathrm{m})\end{array}$ & $\begin{array}{l}D_{\mathrm{EC}}^{\mathrm{NN}} \\
(\mu \mathrm{m})\end{array}$ \\
\hline 0 & $0.52 \pm 0.03$ & $2.8 \pm 0.2$ & $443 \pm 45$ & $471 \pm 36$ \\
10 & $0.48 \pm 0.06$ & $2.6 \pm 0.1$ & $459 \pm 36$ & $483 \pm 30$ \\
30 & $0.48 \pm 0.03$ & $3.0 \pm 0.4$ & $431 \pm 33$ & $461 \pm 30$ \\
60 & $0.51 \pm 0.02$ & $2.8 \pm 0.5$ & $464 \pm 33$ & $489 \pm 34$
\end{tabular}

The error shows the standard deviation

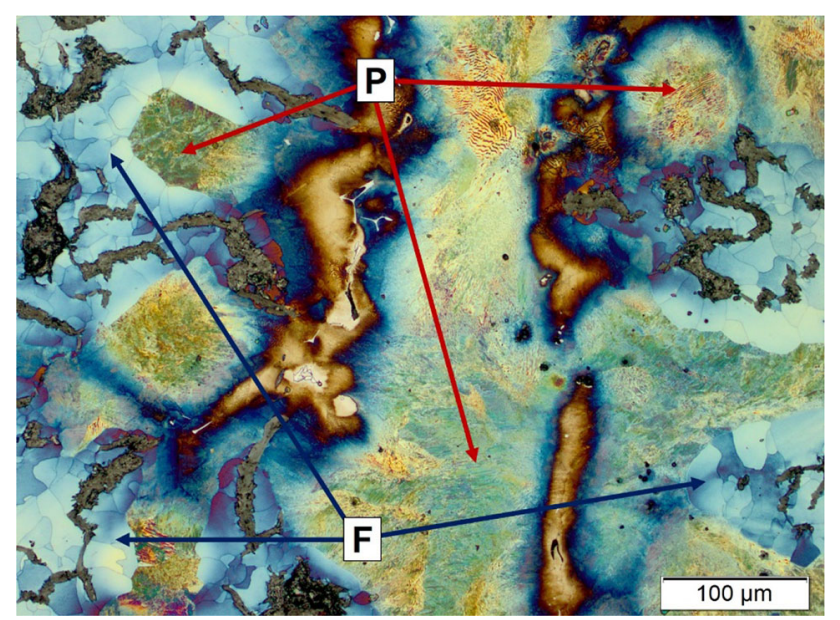

Figure 7. Micrograph of the sample after $60 \mathrm{~min}$ of isothermal coarsening showing pearlite $(P)$ and ferrite (F).

primary austenite and the size of the interdendritic channels do not influence the size and distribution of eutectic cells, nor the nodularity and type of graphite particles in CGI.

Analyzing the microstructures in Figure 4, it can be observed that the presence of $\mathrm{Cu}, \mathrm{Mn}$, and $\mathrm{Sn}$ in the alloy promoted the stabilization of pearlite inside the coarsened primary dendrites in the regions away from the graphite particles for all coarsening times, as shown in Figure 7. It can also be observed that ferrite surrounds the compacted graphite particles as its formation is associated with the compacted morphology of graphite. ${ }^{1}$ As described earlier, the fraction of austenite and eutectic cells are not affected by coarsening time. Thus, we can expect a similar ratio of pearlite/ferrite in all the micrographs, independent of the coarsening time. Furthermore, the pearlite lamellar spacing, PLS, reported in Table 4, is not significantly influenced by coarsening time, thus indicating that the morphology of primary austenite does not influence the eutectoid reaction.
Table 4. Pearlite Lamellar Spacing (PLS) as a Function of Coarsening Time

\begin{tabular}{ll}
\hline Coarsening time $(\mathrm{min})$ & PLS $(\mu \mathrm{m})$ \\
\hline 0 & $0.38 \pm 0.10$ \\
10 & $0.37 \pm 0.08$ \\
30 & $0.34 \pm 0.08$ \\
60 & $0.33 \pm 0.11$ \\
\hline
\end{tabular}

The error shows the standard deviation

Table 5. Ultimate Tensile Strength (UTS) as a Function of Coarsening Time

\begin{tabular}{ll}
\hline Coarsening time $(\mathrm{min})$ & UTS $(\mathrm{MPa})$ \\
\hline 0 & $311 \pm 2$ \\
10 & $298 \pm 3$ \\
30 & $276 \pm 4$ \\
60 & $267 \pm 4$ \\
\hline
\end{tabular}

The error shows the standard deviation

\section{Ultimate Tensile Strength as a Function of the Microstructural Characteristics}

UTS values from the MTT are shown in Table 5 and as a function of the cube root of coarsening time in Figure 8a. A linear decrease in UTS is observed as coarsening time increases. Given that the only microstructural characteristics showing the influence of the coarsening time are those of primary austenite, UTS is shown as a function of the morphological characteristics of primary austenite (SDAS, $M_{\gamma}, D_{\mathrm{ID}}^{\mathrm{Hyd}}$ and $D_{\gamma}^{\mathrm{NN}}$ ) in Figure $8 \mathrm{~b}$. Again, it can be observed that UTS decreases linearly. From the primary austenite characteristics, we observe how UTS does not correlate well with SDAS for the sample of $60 \mathrm{~min}$ of coarsening. This is due to that SDAS is not an accurate characteristic of the primary austenite morphology for long coarsening times, as seen in Figure 5. These results show that $M_{\gamma}$ and $D_{\mathrm{ID}}^{\mathrm{Hyd}}$, the parameters related to the surface area of primary austenite and the interdendritic region, describe more accurately the effect of primary austenite morphology on UTS.

\section{Conclusions}

The primary austenite in a hypoeutectic CGI alloy has been coarsened isothermally for different times, up to $60 \mathrm{~min}$. The cooling conditions for the subsequent eutectic and eutectoid reactions after the isothermal treatment were kept similar. This way, the morphology of primary austenite could be altered independently of the eutectic and eutectoid microstructures. 


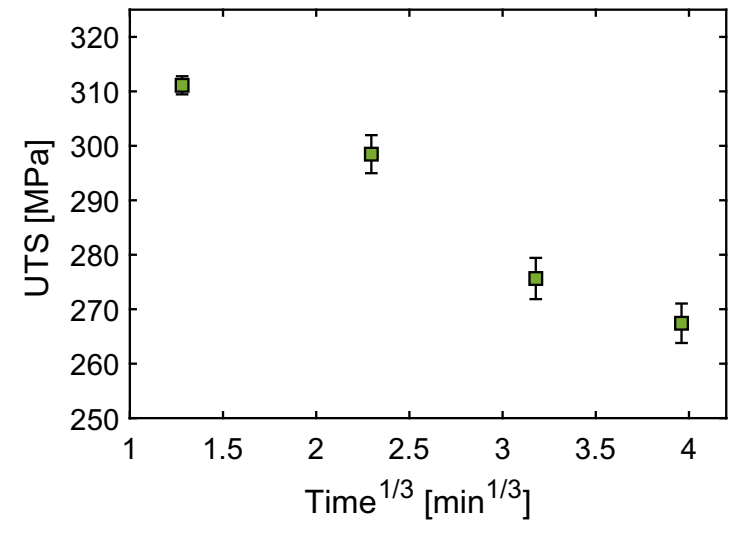

(a)

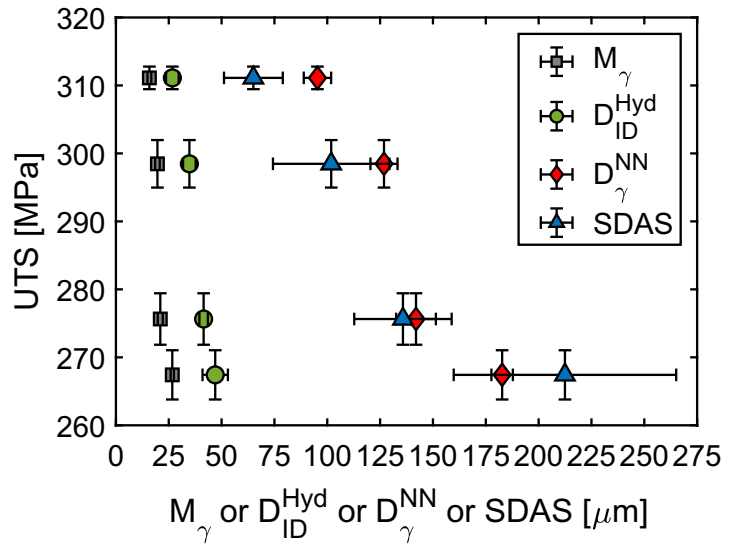

(b)

Figure 8. (a) UTS as a function of coarsening time, and (b) UTS as a function of primary austenite characteristics. The error bars show the standard deviation.

Primary austenite in CGI coarsens according to the Ostwald ripening model, and its morphology is accurately described by the parameters related to the surface area of primary austenite, $M_{\gamma}$ and $D_{\mathrm{ID}}^{\mathrm{Hyd}}$. SDAS deviates for long coarsening times.

The characteristics of the eutectic and eutectoid microstructure in CGI are not significantly affected by the changes in the morphology of primary austenite. This indicates that the surface area and the size of the interdendritic regions do not control the size and distribution of graphite particles and eutectic cells, and hence, do not influence the nucleation frequency and growth of eutectic cells or graphite particles in CGI. The similar cooling conditions during the eutectic reaction and the constant alloy composition promoted similar eutectic microstructures for all coarsening times.

The UTS decreased with the increasing coarseness of primary austenite. This demonstrates the strong influence of primary austenite morphology on the UTS of hypoeutectic CGI alloys for similar eutectic and eutectoid microstructures. These results for CGI are in good agreement with the recent model by Fourlakidis and Diószegi ${ }^{34}$ for hypoeutectic pearlitic LGI, using the hydraulic diameter of the interdendritic region, $D_{\mathrm{ID}}^{\mathrm{Hyd}}$, in the Griffith fracture model to replace the graphite length.

The effect of primary austenite on UTS in CGI has been shown isolated, stressing the importance of incorporating the morphology of the primary microstructure in the models for mechanical properties of hypoeutectic alloys. However, the contributions to strength from graphite morphology, eutectic cell size, pearlite/ferrite ratio, and pearlite lamellar spacing are not to be neglected and require future work.

\section{Acknowledgements}

Open access funding provided by Jönköping University. This research was funded by VINNOVA, through the research projects Cast Design (2013-03303) and SPOFIC II (2013-04720), and by KK-Stiftelsen through the research project Lean Cast (2018-0033). The projects are a collaboration between Scania CV AB, Volvo Group Trucks, SinterCast, RISE SWECAST, and Jönköping University. All support and participating personnel from the above institutions are gratefully acknowledged by the authors.

Open Access This article is licensed under a Creative Commons Attribution 4.0 International License, which permits use, sharing, adaptation, distribution and reproduction in any medium or format, as long as you give appropriate credit to the original author(s) and the source, provide a link to the Creative Commons licence, and indicate if changes were made. The images or other third party material in this article are included in the article's Creative Commons licence, unless indicated otherwise in a credit line to the material. If material is not included in the article's Creative Commons licence and your intended use is not permitted by statutory regulation or exceeds the permitted use, you will need to obtain permission directly from the copyright holder. To view a copy of this licence, visit http://creativecommons. org/licenses/by/4.0/.

\section{REFERENCES}

1. M. König, Literature review of microstructure formation in compacted graphite iron. Int. J. Cast Met. Res. 23(3), 185-192 (2010)

2. D.M. Stefanescu, Mechanical properties of compacted graphite iron cast iron science and technology, in Cast Iron Science and Technology, ed. by D.M. Stefanescu (ASM International, Cleveland, 2017)

3. R.W. Gregorutti, J.E. Grau, Mechanical properties of compacted graphite cast iron with different 
microstructures. Int. J. Cast Met. Res. 27(5), 275-281 (2014)

4. W. Kurz, D. Fisher, Fundamentals of Solidification, 1986 (Trans Tech Publications, Switzerland, 1989)

5. P.W. Voorhees, The theory of ostwald ripening. J. Stat. Phys. 38(1-2), 231-252 (1985)

6. D. Kammer, P.W. Voorhees, The morphological evolution of dendritic microstructures during coarsening. Acta Mater. 54(6), 1549-1558 (2006)

7. J.C. Hernando, E. Ghassemali, A. Diószegi, The morphological evolution of primary austenite during isothermal coarsening. Mater. Charact. 131, 492-499 (2017)

8. S.P. Marsh, M.E. Glicksman, Overview of geometric effects on coarsening of mushy zones. Metall. Mater. Trans. A 27(3), 557-567 (1996)

9. T. Cool, P.W. Voorhees, The evolution of dendrites during coarsening: fragmentation and morphology. Acta Mater. 127, 359-367 (2017)

10. H. Neumann-Heyme, K. Eckert, C. Beckermann, General evolution equation for the specific interface area of dendrites during alloy solidification. Acta Mater. 140, 87-96 (2017)

11. J.C. Hernando, J. Elfsberg, A.K. Dahle, A. Diószegi, Evolution of primary austenite during coarsening and impact on eutectic microstructure in $\mathrm{Fe}-\mathrm{C}-\mathrm{Si}$ alloys. Materialia 7, 100391 (2019)

12. N.L.M. Veldman, A.K. Dahle, D.H. Stjohn, L. Arnberg, Dendrite coherency of Al-Si-Cu alloys. Metall. Mater. Trans. A 32(1), 147-155 (2001)

13. L. Collini, G. Nicoletto, R. Konečná, Microstructure and mechanical properties of pearlitic gray cast iron. Mater. Sci. Eng., A 488(1), 529-539 (2008)

14. D.M. Stefanescu, G. Alonso, P. Larrañaga, R. Suarez, On the stable eutectic solidification of iron-carbonsilicon alloys. Acta Mater. 103, 103-114 (2016)

15. G.L. Rivera, R.E. Boeri, J.A. Sikora, Solidification of gray cast iron. Scripta Mater. 50(3), 331-335 (2004)

16. C. Chuang, D. Singh, P. Kenesei, J. Almer, J. Hryn, R. Huff, 3D quantitative analysis of graphite morphology in high strength cast iron by high-energy X-ray tomography. Scripta Mater. 106, 5-8 (2015)

17. J. Tartera, N. Llorca-lsern, M. Marsal, J.L. Rojas, Similarities of nucleation and growth of spheroidal and compacted graphite. Int. J. Cast Met. Res. 16(1-3), 131-135 (2003)

18. S.V. Subramanian, D.A.R. Kay, G.R. Purdy, Compacted graphite morphology control. AFS Trans. 82(179), 589-603 (1982)

19. F. Mampaey, D. Habets, J. Plessers, F. Seutens, The use of oxygen activity measurement to determine optimal properties of ductile iron during production. Foundry Res./Giessereiforschung 60(1), 2-19 (2008)

20. K. Yamane, H. Yasuda, A. Sugiyama, T. Nagira, M. Yoshiya, K. Morishita, K. Uesugi, A. Takeuchi, Y. Suzuki, Influence of $\mathrm{Mg}$ on solidification of hypereutectic cast iron: X-ray radiography study. Metall. Mater. Trans. A 46(11), 4937-4946 (2015)

21. S. Dawson, Process control for the production of compacted graphite iron, in 106th AFS Casting Congress, AFS, Kansas City, USA (2002)

22. ISO, ISO 16112: Compacted (vermicular) graphite cast irons-Classification (ISO, Switzerland, 2017)

23. R. Suárez, J. Sertucha, P. Larrañaga, J. Lacaze, Active Mg estimation using thermal analysis: a rapid method to control nodularity in ductile cast iron production. Metall. Mater. Trans. B 47(5), 2744-2753 (2016)

24. S. Kim, S.L. Cockcroft, A.M. Omran, Optimization of the process parameters affecting the microstructures and properties of compacted graphite iron. J. Alloy. Compd. 476(1-2), 728-732 (2009)

25. X.J. Sun, Y.X. Li, X. Chen, Controlling melt quality of compacted graphite iron. Mater. Sci. Eng., A 466(1-2), 1-8 (2007)

26. W. Xu, M. Ferry, Y. Wang, The effect of ausferrite formation on the mechanical properties of gray iron. Scripta Mater. 51(7), 705-709 (2004)

27. A. Griffith Alan, VI. The phenomena of rupture and flow in solids. Philos. Trans. R. Soc. Lond. 221(582-593), 163-198 (1921)

28. C.E. Bates, Alloy element effects on grey iron properties: part II, in AFS Transactions (1986)

29. D.D. Goettsch, J.A. Dantzig, Modeling microstructure development in gray cast irons. Metall. Mater. Trans. A 25(5), 1063-1079 (1994)

30. T.J. Baker, The fracture resistance of flake graphite cast iron. Int. J. Mater. Eng. Appl. 1(1), 13-18 (1978)

31. T. Willidal, W. Bauer, P. Schumacher, Stress/strain behaviour and fatigue limit of grey cast iron. Mater. Sci. Eng., A 413-414, 578-582 (2005)

32. L. Elmquist, A. Diószegi, Relation between SDAS and eutectic cell size in grey iron. Int. J. Cast Met. Res. 23(4), 240-245 (2010)

33. A. Catalina, X. Guo, D. Stefanescu, L. Chuzhoy, M. Pershing, Prediction of room temperature microstructure and mechanical properties in gray iron castings, in AFS Transactions (2000)

34. V. Fourlakidis, A. Diószegi, A generic model to predict the ultimate tensile strength in pearlitic lamellar graphite iron. Mater. Sci. Eng., A 618, 161-167 (2014)

35. A. Boudot, V. Gerval, D. Oquab, J. Lacaze, H. Santos, The role of manganese and copper in the eutectoid transformation of spheroidal graphite cast iron. Metall. Mater. Trans. A 28(10), 2015-2025 (1997)

36. ASTM, ASTM E1999-18: Standard Test Method for Analysis of Cast Iron by Spark Atomic Emission Spectrometry (2018)

37. J.C. Hernando, B. Domeij, D. González, J.M. Amieva, A. Diószegi, New experimental technique for nodularity and $\mathrm{Mg}$ fading control in compacted graphite iron production on laboratory scale. Metall. Mater. Trans. A 48(11), 5432-5441 (2017) 
38. J.C. Hernando, A. Diószegi, On the primary solidification of compacted graphite iron: microstructure evolution during isothermal coarsening. Mater. Sci. Forum 925, 90-97 (2018)

39. J.C. Hernando, J. Elfsberg, E. Ghassemali, A.K. Dahle, A. Diószegi, The effect of coarsening of primary austenite on the ultimate tensile strength of hypoeutectic compacted graphite $\mathrm{Fe}-\mathrm{C}-\mathrm{Si}$ alloys. Scripta Mater. 168, 33-37 (2019)

40. J.M. Motz, Microsegregations-an easily unnoticed influencing variable in the structural description of cast materials. Pract. Metallogr. 25, 285-293 (1988)

41. M.C. Flemings, T.Z. Kattamis, B.P. Bardes, Dendrite Arm Spacing in Aluminum Alloys, in AFS Transactions (1991), pp 501-506
42. E.E. Underwood, Quantification of microstructures by stereological analysis. J. Histochem. Cytochem. 27(11), 1536-1537 (1979)

43. A. Diószegi, V. Fourlakidis, R. Lora, Austenite dendrite morphology in lamellar graphite iron. Int. J. Cast Met. Res. 28(5), 310-317 (2015)

44. ISO, ISO 16112: Compacted (Vermicular) Graphite Cast Irons-Classification (ISO, Switzerland, 2006)

45. Y. Sun, W.B. Andrews, K. Thornton, P.W. Voorhees, Self-similarity and the dynamics of coarsening in materials. Sci. Rep. 8(1), 17940 (2018)

Publisher's Note Springer Nature remains neutral with regard to jurisdictional claims in published maps and institutional affiliations. 